\title{
Study on policy and measures, standards and certification system of LED lighting industry in Malaysia
}

\author{
Qing Ding ${ }^{1, *}$, Pengcheng $\mathrm{Li}^{1}$, Meng Liu ${ }^{1}$, Xiuying Liang ${ }^{1}$, Haihong Chen ${ }^{1}$, Zhonghang Wang ${ }^{1}$ \\ ${ }^{1}$ Resource and Environment Branch, China National Institute of Standardization, 100191, Beijing, China
}

\begin{abstract}
This paper introduces Malaysia's LED lighting policy measures and standard certification system, investigates policies and measures issued and implemented in recent years to promote the development and promotion of the LED lighting industry, and analyzes the norm leading effect of LED lighting related standards and certification system on the LED lighting markets. It also puts forward the feasibility to strengthen the coordination of LED product standards and labelling with Malaysia, and develop regional technical specifications for LED products.
\end{abstract}

\section{Introduction}

As a new type of green energy-saving lighting product, LED lighting has the characteristics of low energy consumption, strong controllability, rich colors, and long life. It is known as a new generation of lighting and green light sources. With the implementation of the concept of global energy conservation and environmental protection and the support of industry policies in various countries, its research and development, application and promotion have continued to expand in recent years.

Southeast Asia is gradually developing into a very dynamic LED lighting market, thanks to the rapid economic growth, large infrastructure investment, and large population and market demand for lighting. According to statistics, in 2017, Southeast Asia accounted for about $8 \%$ of China's LED lighting export market share. Malaysia is one of the founding countries of ASEAN and an important economy in Southeast Asia. The geographical position is superior, close to the Strait of Malacca, which can radiate the entire Southeast Asia region of 600 million people, while exporting to the Commonwealth countries enjoy tariff-free preferential policies. Malaysia is also the second largest procurement center in the entire Middle East. The development of its LED lighting industry is a microcosm of the overall situation in Southeast Asia.

Therefore, studying the LED lighting policy and regulatory system, application status and industrial technology characteristics of Southeast Asian countries represented by Malaysia, and proposing relevant cooperation suggestions will promote China and Southeast Asia to strengthen cooperation in LED lighting policies, standards, technology and market transformation. It is also helpful to promote the green development of the LED lighting industry, and make positive contributions to global energy conservation, emission reduction, and climate change.

\section{Policy and measures for the LED lighting industry}

\subsection{Policy and measures for green and sustainable development}

In order to realize a low-carbon economy and achieve sustainable development, the Malaysian government has successively introduced a series of policies and measures to promote energy conservation, emission reduction, green technology development, and economic transformation in recent years.

In 2009, the Malaysian government launched the National Green Technology Policy (NGTP) to achieve a low-carbon economy and sustainable development. The policy proposes expenditure targets and priorities in the fields of energy, construction, transportation, waste and water resources by 2030 to achieve Malaysia's green goals. Malaysia's National Energy Efficiency Action Plan (2015) released in 2015 proposed a plan to save $50,594 \mathrm{GWh}$ of electricity by 2025 , corresponding to a $6 \%$ reduction in electricity demand growth.

In order to achieve these goals of energy conservation, emission reduction, and green development as above, the Malaysian government plans to adopt some measures with significant energy conservation and emission reduction effects. For example, in the field of electrical and electronics, the Ministry of Science, Technology and Innovation (MOSTI) of Malaysia will provide R\&D and technological innovation for 15 breakthrough projects (Entry Point Projects, EPPs) in the solar energy, LED, industrial electronics and household appliances industries. The plan identified the electronics industry as one of the main driving industries for Malaysia's economic development, and determined the goal of developing at least five Malaysian LED lighting manufacturers into regional and global brands by 2020. From 2012 to 2016, at least one local SSL company became a global 
well-known brand in the SSL market every year.

\subsection{Policies and actions of green and efficient lighting}

The electricity consumption of residential lighting in Malaysia accounts for approximately $10.0 \%$ of the total electricity consumption of residents. Lighting electricity consumption in the commercial sector accounts for approximately $21.8 \%$ of the overall commercial electricity demand. In the commercial sector, the public management sector uses the most lighting power, accounting for $14.7 \%$ of all lighting power demand. Therefore, the Malaysian government attaches great importance to the promotion and application of high-efficiency and energy-saving lighting products such as LED lighting, and has successively introduced a series of policy measures to promote the application of high-efficiency lighting products such as LED.

Since 2011, Malaysia has banned the sale and import of incandescent lamps. From 2012 to 2013, Malaysia banned the production, import and sale of incandescent lamps. Malaysia banned or phased out all incandescent lamps and traditional lighting in buildings and real estate projects from 2014.

Since 2015, the Malaysian government has launched the LED lighting renovation project, which is an important step for Malaysia to enter the era of energy saving and environmental protection.

Malaysia plans to gradually replace the country's street lights with LED bulbs from September 2019 to reduce power consumption by $50 \%$. It is expected that all domestic street lights will be replaced with LED light sources by 2020, and the replacement of signs of shops and buildings with LED lights will be discussed. Penang is committed to becoming the first state in Malaysia to use LED street lights. Penang plans to replace all its street lights with LED lights in order to save nearly $60 \%$ of electricity bills.

Selangor and other state governments have promulgated ordinances to compel the use of LED products as light sources in new buildings from 2019. MBPJ Petaling Jaya City Council requires all new commercial buildings in the city to use LED lighting in order to achieve the 2030 green and sustainable city goal.

The Energy Efficiency Sustainability Program aims to improve Malaysia's energy efficiency mainly through cooperation between government and public utility companies, home appliance, equipment manufacturers, and electrical appliance retailers. According to the plan, Malaysians can exchange used non-energy-saving electrical equipment for five-star energy-saving equipment and receive discounts. Companies can also get discounts if they replace their non-energy-efficient refrigerators and air conditioners with energy-efficient equipment.

In 2015, with the support of the British Government Prosperity Fund, CarbonTrust cooperated with a green technology company to compile a catalog of LED lighting suppliers and installers in Malaysia, and developed a set of LEDs that can be replicated in the public and private sectors. Lighting renovation methods, and nearly 150 personnel from small and medium-sized enterprises have been trained in LED lighting, and LED technology and its advantages have been popularized in the form of cases.

\subsection{Fiscal policy}

Enterprises that receive investment tax subsidies can enjoy $100 \%$ tax subsidies for qualified capital expenditure (QCE) from 2013 to 2020 . The subsidy can be used to offset $70 \%$ of the statutory income of the tax year until it is fully utilized in the tax year. The tax subsidy applies to green technology projects related to renewable energy, energy efficiency, green buildings, green data centers and waste management.

From 2013 to 2020, income generated from the use of green technology services is exempt from income tax. The tax subsidy applies to green technology services related to renewable energy, energy efficiency, electric vehicles (EV), green buildings, green data centers, waste management, green certification, and green towns.

Enterprises that receive investment tax subsidies can enjoy $100 \%$ tax subsidies for qualified capital expenditure (QCE) from 2013 to 2020 . The subsidy can be used to offset $70 \%$ of the statutory income of the tax year until it is fully utilized in the tax year. This tax incentive is available for purchasing green technology assets listed in the MyHijau catalog. In this catalog, there are a total of 45 LED lamps, 32 of which are street lamps.

Based on the Investment Promotion Act of 1986, MIDA updated the list of promotion projects and products in 2012, including energy-saving lighting. The items and products on this list are eligible to apply for pioneer status certificates and investment tax subsidies. Companies that have obtained the Vanguard Status Certificate can enjoy a 70\%-100\% income tax deduction for their statutory income for 5 to 10 years. Companies that receive investment tax subsidies can enjoy a tax subsidy of $60 \%-100 \%$ of qualified capital expenditure (QCE) within 5 to 10 years.

As part of the Economic Transformation Plan (ETP), the Green LED Program (Green LED Program) will assist the development of SSL/LED companies to cultivate local leading companies. The project will provide funds for the development or transformation of commercially viable LED products, and provide some funds for enterprises to purchase or improve manufacturing equipment, testing technology, manufacturing process or monitoring technology to obtain international certification. For the purchase of high-level automation equipment and monitoring tools or to obtain international certification, the project will provide $50 \%$ of financial assistance not exceeding 500,000 ringgits, and the company needs to invest $10 \%$ as a project commitment.

Manufacturing export enterprises are entitled to $10 \%-100 \%$ of eligible tax subsidies for newly increased exports, and can deduct up to $70 \%$ of statutory income.

Green lighting has become an important issue in the development of Malaysia's green industry. As mentioned earlier, in recent years, the Malaysian government has proposed and implemented a series of policy measures to promote technological innovation and application, and 
accelerate the development of green transformation. The Malaysian government is promoting the value and market development of the entire LED industry supply chain.

As early as 2008, LED products exported by Malaysia accounted for $10 \%$ of the global LED market, most of which were in the field of lighting. Malaysia has great potential to become a global hub for LED lighting. However, although there are many companies in the downstream of the LED lighting industry (such as packaging and testing) in Malaysia, there are few upstream companies engaged in chip and application research and development. Based on this, Malaysia's Economic Transformation Plan (ETP) has developed a breakthrough project (EPP) for the LED industry, which will actively cultivate Malaysia's strong position as a LED lighting product packaging center and attract more substrate and epitaxial manufacturers to complete LED in Malaysia Value chain, while establishing more LED wafer manufacturing plants to further develop the national LED cluster. The plan puts forward the goal of developing at least five Malaysian LED lighting manufacturers into regional and global brands by 2020 . From 2012 to 2016, at least one local LED lighting company became a global famous brand in the LED lighting market every year.

\section{Standards and certification system}

\subsection{LED lighting standards system}

The formulation and management of Malaysian standards is the responsibility of the Department of Standard Malaysia (DSM), which authorizes The Standard and Industrial Research Institute of Malaysia (SIRIM) to manage the specific matters of standard formulation. The Malaysian National Commission of Illumination (MyCIE) is the working committee of the International Commission of Illumination (CIE) to implement projects. It is composed of people from industries and universities who are interested in the field. MyCIE regularly organizes meetings and publishes research results.

The Institute of Standards and Industrial Research of Malaysia (SIRIM) is the main standard-setting body and certification body in the national standards and quality organization. It has formulated more than 2500 Malaysian standards and plans to launch a variety of Malaysian product and service standards 6000 by 2010 In addition, at the same time, it can also provide a variety of domestic and foreign certifications.

Considering the huge global demand for LEDs, the Malaysian Bureau of Standards will help local companies adapt to international standards and accelerate the industry's adoption of Malaysia Standards (MS) to ensure the production of high-quality LEDs for export and domestic sales. As of May 2019, Malaysia has issued a total of $12 \mathrm{MS}$, covering the safety and performance testing of LEDs, as shown in Table 1. These standards use the International Electrotechnical Commission (IEC) as a guide, and compliance with MS will increase the opportunities for local manufacturers to enter the international market.

Table 1 Malaysia's lighting products standards

\begin{tabular}{|c|c|c|}
\hline No & $\begin{array}{l}\text { Standard } \\
\text { Edition } \\
\text { number }\end{array}$ & Standard Name \\
\hline 1 & $\begin{array}{l}\text { IEC } \\
60598-1: 2012 \\
(\mathrm{P})\end{array}$ & $\begin{array}{l}\text { Luminaires--Part 1: General } \\
\text { requirements and tests }\end{array}$ \\
\hline 2 & $\begin{array}{l}\text { IEC } \\
60838-2-2: 20 \\
08(P)\end{array}$ & $\begin{array}{l}\text { Miscellaneous } \\
\text { lampholders--Part } \\
\text { 2--2:Particular requirements - } \\
\text { Connectors for LED--modules }\end{array}$ \\
\hline 3 & $\begin{array}{l}\text { IEC } \\
61347-1: 2012 \\
(\mathrm{P})\end{array}$ & $\begin{array}{l}\text { Lamp controlgear--Part } 1 \text { : } \\
\text { General and safety requirements }\end{array}$ \\
\hline 4 & $\begin{array}{l}\text { IEC } \\
61347-2-13: 2 \\
012(P)\end{array}$ & $\begin{array}{l}\text { Lamp controlgear--Part 2-13: } \\
\text { Particular requirements for d.c. } \\
\text { or a.c. supplied electronic } \\
\text { control gear for LED modules }\end{array}$ \\
\hline 5 & $\begin{array}{l}\text { IEC } \\
62031: 2011\end{array}$ & $\begin{array}{l}\text { LED modules for general } \\
\text { lighting - Safety specifications }\end{array}$ \\
\hline 6 & $\begin{array}{l}\text { IEC } \\
62384: 2012 \\
(\mathrm{P})\end{array}$ & $\begin{array}{l}\text { DC or AC supplied electronic } \\
\text { controlgear for LED modules - } \\
\text { Performance requirements }\end{array}$ \\
\hline 7 & $\begin{array}{l}\text { IEC } \\
62560: 2012 \\
(P)\end{array}$ & $\begin{array}{l}\text { Self-ballasted LED--lamps for } \\
\text { general lighting services by } \\
\text { voltage > } 50 \mathrm{~V}-\text { Safety } \\
\text { specifications }\end{array}$ \\
\hline 8 & $\begin{array}{l}62504: 2012 \\
(\mathrm{P})\end{array}$ & $\begin{array}{l}\text { General lighting--LEDs and } \\
\text { LED modules - Terms and } \\
\text { definitions }\end{array}$ \\
\hline 9 & $\begin{array}{l}62612: 2012 \\
(\mathrm{P})\end{array}$ & $\begin{array}{l}\text { Self-ballasted LED--lamps for } \\
\text { general lighting services - } \\
\text { Performance } \\
\text { Products }\end{array}$ \\
\hline 10 & $\begin{array}{l}62717: 2012 \\
(\mathrm{P})\end{array}$ & $\begin{array}{l}\text { LED modules for general } \\
\text { lighting--Performance } \\
\text { requirements }\end{array}$ \\
\hline 11 & $\begin{array}{l}62722-1: 2012 \\
(\mathrm{P})\end{array}$ & $\begin{array}{l}\text { Luminaire performance--Part 1: } \\
\text { General requirements }\end{array}$ \\
\hline 12 & $62722-2-1(\mathrm{P})$ & $\begin{array}{l}\text { Luminaire performance--Part } \\
\text { 2--1: Particular requirements for } \\
\text { LED luminaires }\end{array}$ \\
\hline
\end{tabular}

Malaysia has implemented the Minimum Energy Efficiency Performance Requirements (MEPS) since 2013, covering five categories including air conditioners, refrigerators, TVs, household fans and lamps. For household appliances, energy efficiency labels and minimum energy efficiency performance requirements (MEPS) are mandatory. The controlled lamps include IL (MEPS implemented since 2012), CFL (2015), LFL (2015), LED, Ballasts (1996), excluding HI. The energy efficiency standard indicators of lighting products are shown in Table 2:

Table 2 Malaysia's lighting product energy efficiency standard index

\begin{tabular}{|c|c|c|c|c|}
\hline $\begin{array}{l}\text { Lighting } \\
\text { equipment } \\
\text { classification }\end{array}$ & $\begin{array}{l}\text { Energy } \\
\text { efficiency test } \\
\text { standards }\end{array}$ & \multicolumn{3}{|l|}{ MEPS } \\
\hline \multirow{5}{*}{$\begin{array}{l}\text { (a) } \\
\text { Fluorescent } \\
\text { lamp } \\
\text { (b) (CFL) } \\
\text { (c) (LED) } \\
\text { (d) }\end{array}$} & \multirow{5}{*}{$\begin{array}{l}\text { (a)MS IEC } \\
\text { 60969: } \\
\text { (Self-ballasted } \\
\text { fluorescent } \\
\text { lamps for } \\
\text { general }\end{array}$} & \multicolumn{3}{|c|}{ (a) Tubular fluorescent lamp: } \\
\hline & & $\begin{array}{l}\text { Classifi- } \\
\text { cation }\end{array}$ & $(\mathrm{W})$ & $\begin{array}{l}\text { MEPS } \\
(1 \mathrm{~m} / \mathrm{W})\end{array}$ \\
\hline & & $\mathrm{T} 8$ & $18-30$ & 70 \\
\hline & & & $>=31$ & 85 \\
\hline & & T5 & 14 & 80 \\
\hline
\end{tabular}




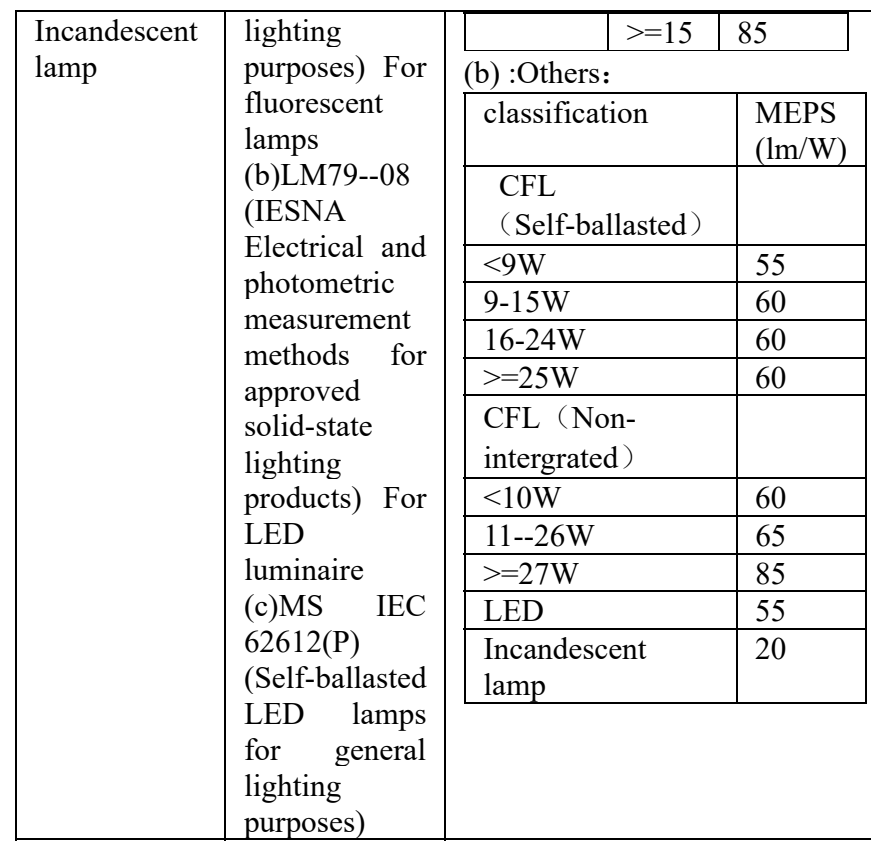

\subsection{Product Certification Program}

Malaysia's laws concerning electrical products include: "Power Supply Act (1990) (PowerSupply Act (1990)) and "Approved of Electrical Equipment (Electricity Regulation) 1994". The former addresses safety requirements related to power supply. The latter stipulates that electrical products manufactured, imported, sold, etc. should meet the requirements of relevant standards before they can obtain a certificate of approval (COA) and affix the SIRIM label/mark before they can be sold on the Malaysian market.

According to the "Electrical Equipment Approval Regulation 1994", product certification labels/marks must be purchased from SIRIM QAS, and certification certificates must be provided at the time of purchase to record the use of the labels. The SIRIM label is only affixed to the main components of the certified electrical equipment, and the components cannot be easily removed. When electrical equipment cannot be affixed with the SIRIM label due to its size and usage, or when the manufacturer of the electrical equipment has joined the SIRIM label licensing program, the electrical equipment manufacturer can affix the SIRIM certification mark.

Sirim QAS was established in 1972, and its responsibility is to provide independent certification and identification for products that comply with relevant standards and regulations to ensure the quality and safety of certified products. The certification schemes provided by Sirim are divided into two types: mandatory and non-mandatory. The SIRIM Eco-Labelling Scheme (SIRIM Eco-Labelling Scheme) is a typical non-mandatory certification scheme.

According to the SIRIM eco-labeling plan, products will be independently tested and verified in accordance with specific eco-label standards and applicable product standards before allowing organizations to use SIRIM eco-labels on their product packaging and promotional materials. In order to ensure the credibility of the SIRIM Eco-Labeling logo, products and organizations will be subject to surveillance audits, and factory audits will be conducted during each label update. During the factory audit, the quality system of the product and the organization will be re-evaluated to ensure continued compliance with SIRIM requirements

\subsection{Energy efficiency labelling system}

The Malaysian energy efficiency label certification is a mandatory certification promulgated and implemented by the Malaysian Energy Commission (ST). All controlled products must pass product safety, performance testing and energy efficiency testing to obtain a ST COA certificate (Certificate of Approval, COA) containing energy efficiency standards. And affix safety and energy efficiency labels before they can be distributed in the Malaysian market. The Malaysian government requires that all products sold on the market have an energy efficiency rating of 2 or above. After obtaining the approval of the Energy Commission, the energy efficiency label will be printed by the manufacturer or importer. The Malaysian Ministry of Standards recognizes the test reports provided by some foreign testing laboratories. The mandatory labeling scheme is applicable to IL, CFL, LED and Ballast. The label format is shown in Figure 1.

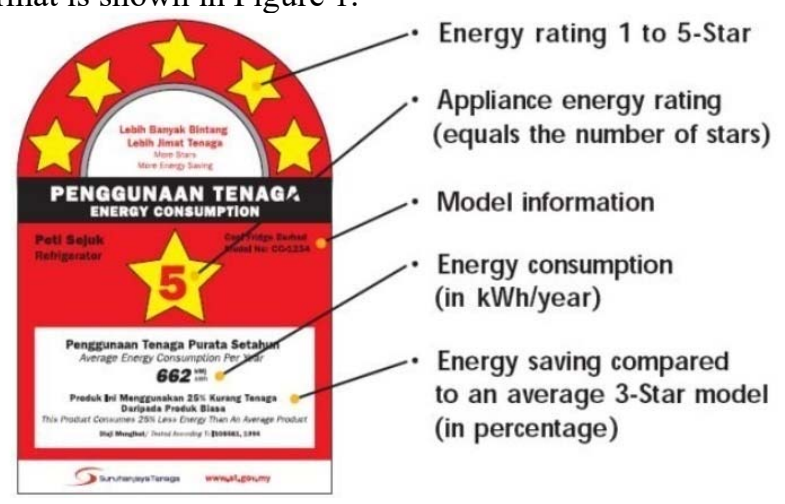

Fig.1 Malaysia’s Mandatory Energy Efficiency Label

\subsection{Testing and certification organizations}

Among the 715 certification bodies in Malaysia, only 3 are qualified to test LED lighting products, of which 2 are located in Penang and 1 is located in Selangor. The SIRIM QAS laboratory in Selangor can carry out the most comprehensive testing items.

International certification is also available in Malaysia. The first LED-SSL certification center outside the United States was established in Penang in 2011. The center is jointly organized by the Northern Corridor Implementation Authority (NCIA) and QAV Technologies Sdn Bhd (QAV), and can be tested in accordance with the American National Standards Institute (ANSI) standards. QAV Technologies was established in 2002, specializing in environmental testing, test equipment customization and test technology development. It is the first company outside the United States to obtain ANSI certification.

\section{Summary and Enlightenment}

The Malaysian government has formulated and 
implemented a series of LED lighting related policy documents, industrial plans, standards and regulations, etc., supporting related project activities that encourage technological innovation and application, and promote the development of the LED industry and product promotion and application to achieve low-carbon economy and sustainable development. With the promotion of the elimination of incandescent lamps, the government has accelerated the promotion of LED road lighting product replacement and public institutions LED lighting product procurement activities, the penetration rate of LED lighting products is rapidly increasing. Malaysia has implemented a mandatory labeling system for energy-saving lamps, LEDs and other lighting products. It has certain standards, specifications, testing and certification foundations, but the capabilities of testing laboratories need to be improved.

In the next step, it is recommended that my country strengthen the comparison study with Malaysia and other key countries and regions of the "Belt and Road" lighting product standard indicators and test methods, study and formulate regional energy efficiency technical specifications for green and efficient LED products, and propose a unified energy efficiency performance indicator system and test methods, Carrying out technical capacity building for energy efficiency standard development, laying the foundation for regional green and efficient product energy efficiency technical specifications to be coordinated, realizing regional green development, and making greater contributions to global energy conservation, emission reduction and climate change.

\section{Acknowledgement}

Supported by China National Institute of Standardization President's Fund Project "Construction and application of standardized technology system for efficient use of resources"(542019Y-6659).

\section{References}

1. ST. Minimum Energy Performance Standards in Malaysia[R].2016.

2. EET Asia. Shining the spotlight on Malaysia's LED industry[R]. 2012.

3. ERI. Regional Report on the Transition to Efficient Lighting in South Asia[R].2014

4. George Wilkenfeld and Associates Pty Ltd. Evaluation of lites.asia and the UNEP en.lighten initiative Southeast Asia and the Pacific Monitoring, Verification and Enforcement Project[R].2016.

5. HoJoey. Market Growth and Uniform Standards Assist LED Manufacturers to Seize Southeast Asian Market[R].2015.

6. LEDs Magazine. MyLED invests in LED manufacturing plant in Malaysia[R]. 2011.

7. LinJudy. Which Country Has the Best LED Policy Among Japan, India, and Malaysia[R]. 2015. 